\title{
Quality of Ground Water and Surface Water in an Area of Individual Sewage Disposal System Use Near Barker Reservoir, Nederland, Colorado, August-September 1998
}

\section{Introduction}

Barker Reservoir is a mountain reservoir adjacent to Nederland, Colorado (fig. 1), that supplies 40 percent of the drinking water for the city of Boulder, Colorado. The local geology is quite complex in this region of the Colorado Mineral Belt (Lovering and Goddard, 1950). The study area is primarily Precambrian igneous and metamorphic rock, except for Quaternary alluvium and colluvium in streambeds and drainages that lead to the reservoir (Gable, 1972). The reservoir is fed by North Beaver Creek and Middle Boulder Creek. Ground water that discharges into Barker Reservoir flows beneath residential developments on the north and south sides of the reservoir. Homes on both sides of the reservoir use individual sewage disposal systems (ISDS's) for disposal of domestic wastewater.

ISDS's, also called septic systems, are a common source for reported contamination of ground water (Canter and Knox, 1986). A system that is not properly designed or maintained may leak sewage into surrounding soil, which then can contaminate surface water or ground water. Even properly functioning systems can contribute considerable loads of chemical constituents that are not removed during infiltration (Wilhelm and others, 1994).

ISDS design can vary, but a basic system includes a septic tank and a leach field. Solid and liquid household waste is transported from the residence through a sewage pipe to the tank, where biological processes begin breakdown of the waste. Solid waste that does not liquefy settles in the tank and must be pumped out periodically. Liquid is decanted from the top of the tank and transported to the leach field where it is distributed through perforated pipe or another means to the soil. Liquid waste flows through the soil, undergoing biological and chemical processes as it travels to the water table.

ISDS effluent is composed of the domestic water supply (ground water or municipal water) that has been modified by chemicals introduced by household activities (detergents, cleaning agents, human wastes, and so forth). ISDS treatment reduces the concentrations of water-quality properties such as biological oxygen demand and total suspended solids by physical and biological processes but has little effect on many chemical constituents such as dissolved ions like sodium and chloride.

The U.S. Geological Survey (USGS), in cooperation with the City of Boulder, Colorado, conducted this study to evaluate whether ISDS's affect the quality of ground water entering Barker Reservoir or its tributaries. This report describes the results of water-quality samples collected in August and September of 1998. Water-quality samples were collected from 12 wells and 10 springs or surfacewater drainages near Barker Reservoir.

\section{Data Collection}

Residential development on the south side of Barker Reservoir is denser and more established than developments on the north side. As the area south of Barker Reservoir was annexed into the Nederland city limits, homes have been connected to a public water system supplied by Middle Boulder Creek upstream from Barker Reservoir. As homes are connected to the public supply, home owners are required to close their wells. Therefore, only one well was available for sampling and analysis in the area. Six springs and surface-water drainages in the area south of Barker Reservoir were sampled in addition to the well (fig. 1). Springs are point discharges of ground water to the land surface. Streamflow during the late summer generally is contributed by ground-water seepage. Data from springs and streams are often indicative of ground-water quality.

North of Barker Reservoir, residents use wells for drinking water and many wells were available for sampling. However, several of the wells are completed far below the water table and may not represent shallow ground water. Therefore, not all of the available wells were sampled, and some wells included in the study may be too deep to show ISDS influence. Eleven wells, three springs, and one drainage site were sampled north of Barker Reservoir (fig. 1).

Water-quality samples were collected from surface- and ground-water sites. Grab samples were collected from small streams and springs during base flow. Samples from springs were collected as

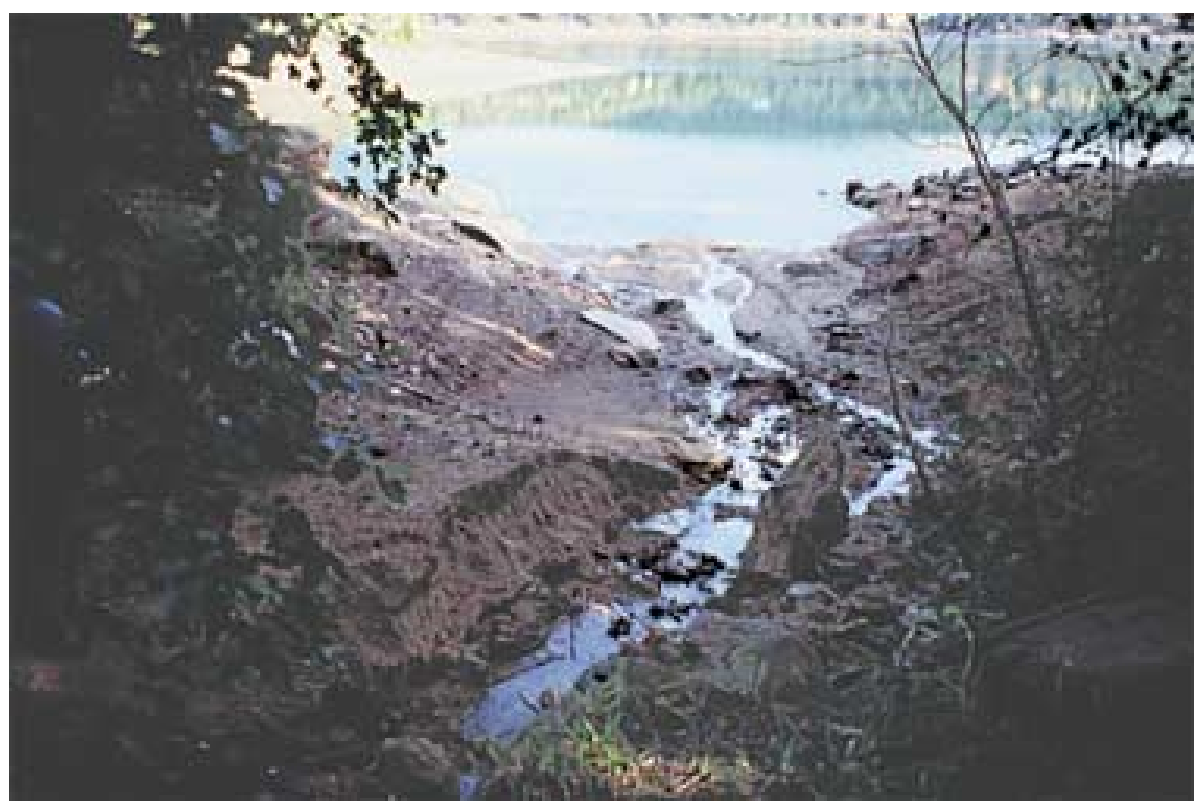

Surface-water drainage into Barker Reservoir (site D1). 

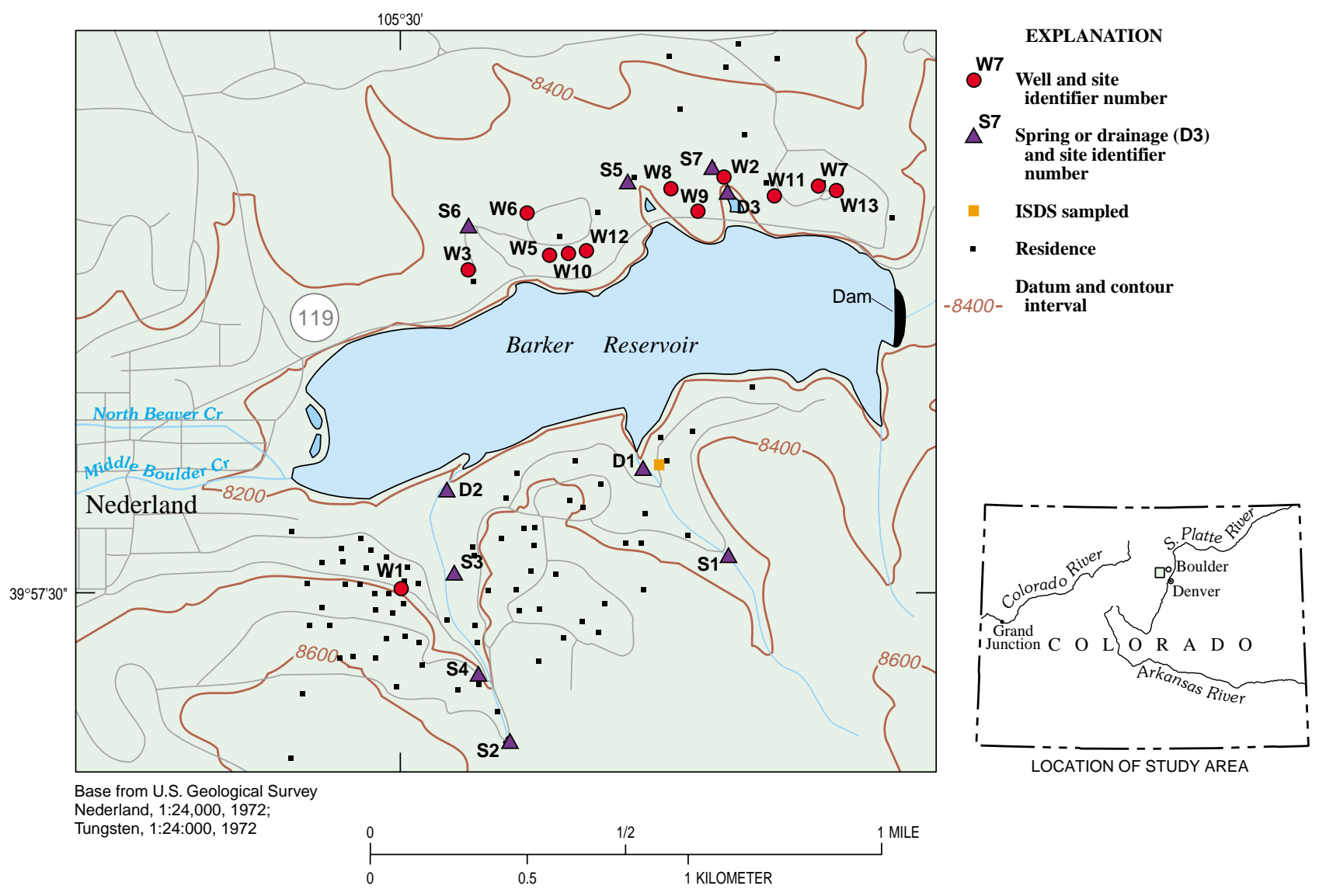

Figure 1. Study area and sampling-site identifiers.

close to the source of the ground-water outflow as possible to reflect groundwater quality. Samples from streams were collected where flow was adequate to fill the sample bottles without disturbing sediment. Ground-water samples were collected from domestic wells using the existing pumps installed and used by the home owners. Well information is presented in table 1 . When possible, well samples were collected at a point in the system before treatment or storage. If it was not possible to collect a sample at a point before a storage tank, the tank was drained before the sample was collected. At least one casing volume, estimated on the basis of well depth and diameter, if known, was purged from the well before sampling. Some of the flow was diverted through clean polyethylene tubing to an open flow-through chamber where field measurements were made for $\mathrm{pH}$, temperature, specific conductance, and dissolved oxygen. When field measurements were stable (three measurements with less than 10 percent difference over 30 minutes), the groundwater sample was collected. An aliquot of sample water was titrated in the field to determine alkalinity. Samples for analysis of dissolved constituents were filtered through a $0.45-\mu \mathrm{m}$ capsule filter. Samples for cation analysis were acidified with nitric acid, and all samples were stored on ice until delivery to the appropriate laboratory for analysis.

Water-quality results are presented in table 2. Water-quality samples from locations hydrologically upgradient from local contaminant sources commonly

Table 1. Well information

[ID, identifier; bls, below land surface; >, greater than; --, data not available]

\begin{tabular}{ccccc}
\hline Site ID & $\begin{array}{c}\text { Water level } \\
\text { (feet bls) }\end{array}$ & $\begin{array}{c}\text { Screened intervals } \\
\text { (feet bls) }\end{array}$ & $\begin{array}{c}\text { Well depth } \\
\text { (feet bls) }\end{array}$ & $\begin{array}{c}\text { Well construction } \\
\text { log available }\end{array}$ \\
\hline W1 & 22.9 & unknown & 100 & no \\
W2 & -- & unknown & 250 & no \\
W3 & 71.3 & unknown & 170 & no \\
W5 & 136.9 & $190-210$ & 360 & yes \\
& & $230-250$ & & yes \\
W6 & -- & $270-350$ & 500 & \\
W7 & & 440-500 & 440 & yes \\
& -- & $230-250$ & & no \\
& & $290-310$ & & yes \\
W8 & 127.8 & unknown & 365 & no \\
W9 & 109.4 & $245-325$ & 325 & no \\
W10 & -- & unknown & 320 & no \\
W11 & -- & unknown & unknown & no \\
W12 & -- & unknown & 180 & \\
W13 & -- & unknown & $>300$ & \\
\hline
\end{tabular}

${ }^{1}$ If well construction $\log$ is not available, well depth is an estimate from the well owner. indicate ambient water-quality conditions in an area. Comparisons between upgradient and downgradient samples can help identify the effects of local contaminant sources. Sites S1 and S2 are springfed streamflows that are upgradient from the development around 
Barker Reservoir (fig. 1). Site S2, however, does not appear to be a pristine site; there is evidence of previous structures near the sample-collection point.

Water-quality constituents that can indicate contamination from septic systems include boron, nitrate, phosphorus, fecal coliform bacteria, and total organic carbon (TOC) (Canter and Knox, 1986; Barber and others, 1988; Wilhelm and others, 1994; Barber and others, 1997). All are possible products of consumption of commercial products or human waste that would be disposed of in an ISDS.

Water levels were measured when possible (table 1). It was not possible to measure water levels at many wells because the measuring tape would not fit down the well with the electrical wiring for the domestic pump.

\section{Individual Sewage Disposal System}

One ISDS was sampled during this study, and analyses were done by the City of Boulder wastewater laboratory (table 2). The sample was collected by dipping a collection bottle into the liquid in the septic tank and pouring that liquid into sample bottles. The result for boron analysis for the ISDS was performed but was considered unreliable by the laboratory. Although it is informative to compare the results to the ground-water and surface-water analyses, this one system may not be representative of other ISDS's in the area.

\section{Quality Assurance/Quality Control}

Duplicates and field blanks were collected at sites S4 and W5 to evaluate precision of laboratory analysis and field procedures (table 2 ). The duplicate analysis data were acceptable for all analyses. The bacteria duplicate sample at S4 was significantly different than the sample, but the difference was exaggerated by the low number of colonies ( 5 and 9 colonies per 100 milliliters). A blank sample is a sample bottle filled in the field with deionized water instead of sample water. Field-blank data were acceptable for all analyses.

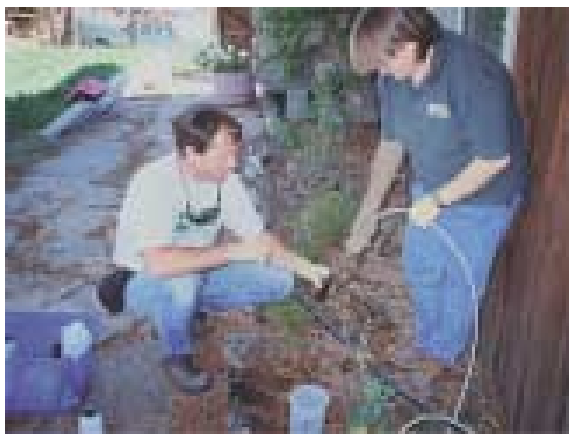

Sample collection from a domestic well.

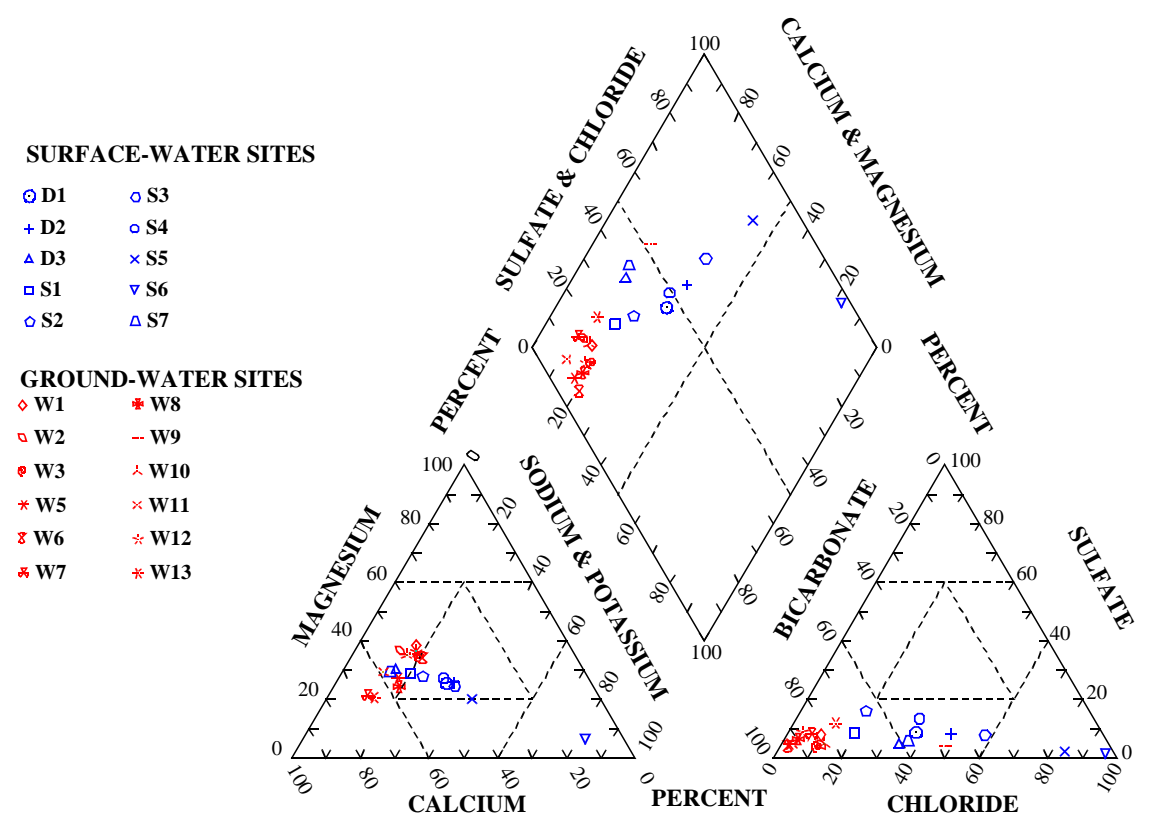

Figure 2. Piper trilinear diagram.

\section{Water Quality}

A Piper trilinear diagram was plotted for the sites discussed in this report (fig. 2). A Piper diagram is a plot that provides a visual representation of the concentrations of major ions in water (Hem, 1992). This diagram can be useful for looking at similarities and differences among water samples. Bar graphs are presented for boron (fig. 3), nitrate and ammonia nitrogen (fig. 4), dissolved phosphorus and dissolved orthophosphorus (fig. 5), fecal coliform bacteria (fig. 6), TOC (fig. 7), and specific ultraviolet absorbance (fig. 8) for the sites discussed in this report.

\section{Major Ions}

Many of the wells are clustered together on the diagram, indicating that they are similar in ion ratios. The Piper plot indicates that for most of the wells, the predominant ions in the ground-water samples were calcium and bicarbonate. Generally, most ground-water samples had smaller concentrations of sulfate and chloride than surface-water sites. Analyses from surface-water sites were less uniform and had a larger percentage of chloride than ground-water sites. Large chloride concentrations in surface water (table 2) possibly were a result of runoff from roads to which salts have been applied. Site S6 had high percentages of sodium and chloride; its ion ratio was not similar to any other sample in this study (table 2). Sites S1 and S2 are surfacewater sites upgradient from roads and development and had lower chloride concentrations than other surface-water sites.
The ISDS was not included on the Piper diagram because the ion analysis was incomplete.

\section{Boron}

Boron is potentially a good indicator of ISDS effects on ground water because (1) natural background concentrations are generally low relative to ISDS effluent, (2) boron does not undergo biological removal during treatment, and (3) boron is not significantly sorbed in the subsurface (Barber and others, 1988).

Boron concentrations in surface water and ground water of the Colorado Front Range typically range from less than $10 \mu \mathrm{g} / \mathrm{L}$ (micrograms per liter) to $40 \mu \mathrm{g} / \mathrm{L}$ (Barnett and others, 1969). Elevated boron concentrations can indicate human influence. Anthropogenic sources of boron include non-chlorine bleaches and fruit (Waggott, 1969).

Most of the ground-water sites have boron concentrations of less than $20 \mu \mathrm{g} / \mathrm{L}$ (fig. 3). Site S1, one of two surface-water sites where boron was below the reporting limit, is a spring upgradient from residential development. The other surface-water site where boron was below the reporting limit was S7, a spring upgradient from site D3, where the boron concentration was $31.9 \mu \mathrm{g} / \mathrm{L}$. The boron concentrations in samples from sites S2, S3, S4, and D2 were greater than expected background concentrations of 10 to $40 \mu \mathrm{g} / \mathrm{L}$. The source of boron at these sites is unknown, but could be near site $\mathrm{S} 2$. The sample for site $\mathrm{S} 2$ was collected as close to the source as feasible, but the spring source was inaccessible beneath a concrete and metal structure. The concentration for 
Table 2. Selected water-quality data for surface-water and ground-water sites near Barker Reservoir, August-September 1998

$\left[{ }^{\circ} \mathrm{C}\right.$, degrees Celsius; $\mu \mathrm{S} / \mathrm{cm}$, microsiemens per centimeter; mg/L milligrams per liter; $\mathrm{NTU}$, nephelometric turbidity units; $\mathrm{CaCO}_{3}$, calcium carbonate; $\mathrm{HCO}_{3}{ }^{-}$, bicarbonate; $\mathrm{mL}$, milliliter; $\mu \mathrm{g} / \mathrm{L}$, micrograms per liter; $n \mathrm{~m}$, nanometer; $<$, less than detection limit; location of sites shown in figure 1$]$

\begin{tabular}{|c|c|c|c|c|c|c|c|c|c|c|c|c|c|c|c|c|c|c|c|c|c|c|c|c|c|c|c|c|}
\hline $\begin{array}{l}\text { Constituent or property } \\
\text { (units) }\end{array}$ & $\begin{array}{c}\text { Reporting } \\
\text { limit }^{1}\end{array}$ & D1 & D2 & D3 & si & s2 & s3 & s4 & $\begin{array}{c}\text { S4 } \\
\text { duplicate }\end{array}$ & $\begin{array}{c}\mathrm{S4} \\
\text { blank }\end{array}$ & s5 & s6 & s7 & w1 & $\mathrm{w}_{2}$ & w3 & w5 & $\begin{array}{c}\text { W5 } \\
\text { duplicate }\end{array}$ & $\begin{array}{c}\text { w5 } \\
\text { blank }\end{array}$ & w6 & w7 & w8 & w9 & w10 & w11 & $\mathrm{w} 12$ & w13 & $\mathrm{ISDS}^{2}$ \\
\hline Date (month and day) 1998 & -- & $08 / 18$ & $08 / 24$ & $08 / 25$ & $08 / 17$ & $08 / 18$ & $08 / 19$ & $08 / 19$ & $08 / 19$ & $08 / 19$ & $08 / 24$ & $08 / 26$ & $08 / 31$ & $08 / 20$ & $08 / 25$ & $08 / 26$ & $08 / 27$ & $08 / 27$ & $08 / 27$ & $08 / 31$ & $09 / 01$ & $09 / 01$ & $09 / 02$ & $09 / 02$ & $09 / 08$ & $\begin{array}{ll}09 / 08 \\
\end{array}$ & $09 / 09$ & -- \\
\hline Time & -- & 1025 & 1000 & 1115 & 1035 & 1305 & 1105 & 1310 & 1315 & 1350 & 1320 & 1155 & 1315 & 1045 & 1040 & 945 & 1130 & 1140 & 1200 & 1029 & 1010 & 1345 & 1015 & 1315 & 1020 & 1305 & 1315 & -- \\
\hline Temperature $\left({ }^{\circ} \mathrm{C}\right)$ & -- & 11.2 & 10.3 & 12.0 & 11.9 & 7.7 & 10.2 & 7.2 & -- & -- & 8.0 & 17.0 & 11.2 & 9.9 & 9.6 & 9.5 & 10.3 & -- & - & 12.1 & 9.1 & 12.3 & 11.5 & 13.7 & 9.3 & 10.3 & 9.4 & -- \\
\hline $\mathrm{pH}-$ field ( $\mathrm{pH}$ units) & -- & 7.8 & 7.8 & 7.9 & 6.6 & 7.2 & 6.4 & 6.7 & -- & -- & 6.5 & 6.7 & 6.5 & 7.1 & 7.2 & 6.5 & 7.1 & -- & - & 6.5 & 7.6 & 7.1 & 6.3 & 6.8 & 7.3 & 6.7 & 7.1 & -- \\
\hline $\mathrm{pH}-\mathrm{lab}$ (pH units) & 0.1 & 7.4 & 8.0 & 7.9 & 6.8 & 7.2 & 6.6 & 6.6 & 6.6 & 6.9 & 6.6 & 7.0 & 6.9 & 7.1 & 7.3 & 6.6 & 7.1 & 7.1 & 7.4 & 6.7 & 7.8 & 7.2 & 6.4 & 6.8 & 7.3 & 7.0 & 7.1 & -- \\
\hline Specific conductance-field $(\mu \mathrm{S} / \mathrm{cm})$ & -- & 220 & 315 & 414 & 137 & 245 & 345 & 228 & -- & -- & 758 & 2,620 & 396 & 266 & 548 & 226 & 286 & -- & -- & 197 & 384 & 448 & 415 & 302 & 385 & 231 & 484 & -- \\
\hline Specific conductance-lab $(\mu \mathrm{S} / \mathrm{cm})$ & 1.0 & 218 & 312 & 412 & 136 & 248 & 341 & 226 & 227 & 1.46 & 741 & 2,850 & 390 & 266 & 542 & 221 & 284 & 282 & 1.83 & 200 & 385 & 447 & 412 & 311 & 400 & 231 & 486 & -- \\
\hline Dissolved oxygen—field $(\mathrm{mg} / \mathrm{L})$ & -- & 8.4 & 8.4 & 7.9 & 5.7 & 8.4 & 6.4 & 7.6 & -- & -- & 7.4 & 6.4 & 4.0 & 5.6 & 5.2 & 1.4 & 0.3 & - & - & 3.7 & 1.7 & 1.5 & 6.4 & 3.8 & 5.3 & 2.2 & 5.3 & -- \\
\hline Turbidity — field (NTU) & -- & 207.0 & 11.3 & 21.0 & 1.7 & 33.6 & 10.9 & 17.7 & -- & - & 0.5 & 1.9 & 6.3 & 33.0 & 95 & 8.2 & 3.2 & - & - & 8.3 & 1.9 & 36.6 & 42.2 & 84.4 & 1.1 & 29.1 & 1.7 & -- \\
\hline Alkalinity—field (mg/L as $\mathrm{CaCO}_{3}$ ) & -- & 50 & 56 & 113 & 40 & 68 & 46 & 44 & -- & -- & 41 & 27 & 97 & 93 & 228 & 87 & 131 & -- & -- & 89 & 155 & 211 & 92 & 121 & 184 & 101 & 156 & -- \\
\hline Alkalinity-lab (mg/L as $\left.\mathrm{CaCO}_{3}\right)$ & 1.0 & 47 & 65 & 110 & 51 & 81 & 56 & 55 & 55 & 1.4 & 48 & 29 & 110 & 100 & 240 & 88 & 140 & 140 & 1.6 & 97 & 170 & 210 & 90 & 140 & 200 & 99 & 160 & 180 \\
\hline Bicarbonate-field ( $\mathrm{mg} / \mathrm{L}$ as $\mathrm{HCO}_{3}^{-}$) & -- & 61 & 68 & 138 & 49 & 83 & 56 & 54 & -- & -- & 50 & 33 & 118 & 113 & 278 & 106 & 160 & -- & -- & 109 & 189 & 257 & 112 & 148 & 224 & 123 & 190 & -- \\
\hline Fecal coliform bacteria (number colonies per $100 \mathrm{~mL}$ ) & -- & 280 & 27 & 101 & 0 & 6 & 32 & 9 & 5 & 0 & 0 & 0 & 0 & 4 & 0 & 0 & 0 & 0 & 0 & 0 & 0 & 0 & 0 & 0 & 0 & 0 & 0 & -- \\
\hline Dissolved ammonia, nitrogen (mg/L) & 0.02 & 0.08 & $<0.02$ & 0.49 & 0.05 & 0.07 & 0.07 & 0.06 & 0.07 & 0.06 & $<0.02$ & $<0.02$ & 0.04 & 0.06 & $<0.02$ & $<0.02$ & $<0.02$ & $<0.02$ & $<0.02$ & 0.03 & 0.03 & 0.03 & 0.04 & 0.02 & 0.02 & 0.03 & 0.05 & 29 \\
\hline Dissolved nitrite-nitrogen $(\mathrm{mg} / \mathrm{L})$ & 0.01 & 0.02 & $<0.01$ & 0.15 & $<0.01$ & $<0.01$ & $<0.01$ & $<0.01$ & $<0.01$ & $<0.01$ & $<0.01$ & $<0.01$ & $<0.01$ & $<0.01$ & $<0.01$ & $<0.01$ & $<0.01$ & $<0.01$ & $<0.01$ & $<0.01$ & 0.01 & $<0.01$ & $<0.01$ & $<0.01$ & $<0.01$ & $<0.01$ & $<0.01$ & 0.002 \\
\hline Dissolved nitrite plus nitrate $(\mathrm{mg} / \mathrm{L})$ & 0.05 & 2.3 & 2.5 & 1.9 & $<0.05$ & 0.14 & 1.9 & 1.8 & 1.8 & $<0.05$ & 4.8 & 0.07 & 1.3 & 2.4 & $<0.05$ & 0.81 & $<0.05$ & $<0.05$ & $<0.05$ & $<0.05$ & 1.3 & 0.39 & $<0.05$ & $<0.05$ & $<0.05$ & $<0.05$ & 9.3 & 3.1 \\
\hline $\begin{array}{l}\text { Total ammonia nitrogen and organic nitrogen } \\
(\mathrm{m} / \mathrm{L})\end{array}$ & 0.1 & 0.4 & 0.1 & 0.9 & $<0.1$ & 0.1 & 0.1 & $<0.1$ & $<0.1$ & $<0.1$ & 0.1 & $<0.1$ & 0.1 & -- & - & - & - & -- & - & -- & -- & -- & - & - & - & - & - & -- \\
\hline $\begin{array}{l}\text { Dissolved ammonia, nitrogen and organic nitrogen } \\
(\mathrm{mg} / \mathrm{L})\end{array}$ & 0.1 & 0.2 & 0.1 & 0.6 & $<0.1$ & $<0.1$ & 0.1 & $<0.1$ & $<0.1$ & $<0.1$ & $<0.1$ & $<0.1$ & 0.1 & $<0.1$ & $<0.1$ & $<0.1$ & $<0.1$ & $<0.1$ & $<0.1$ & $<0.1$ & $<0.1$ & $<0.1$ & $<0.1$ & $<0.1$ & $<0.1$ & $<0.1$ & $<0.1$ & 31.46 \\
\hline Total phosphorus (mg/L) & 0.01 & 0.06 & $<0.01$ & 0.22 & $<0.01$ & 0.03 & $<0.01$ & 0.03 & 0.03 & $<0.01$ & $<0.01$ & $<0.01$ & $<0.01$ & -- & - & -- & - & - & - & - & - & - & - & - & - & -- & - & 19.2 \\
\hline Dissolved phosphorus (mg/L) & 0.01 & $<0.01$ & 0.01 & 0.15 & $<0.01$ & $<0.01$ & $<0.01$ & 0.03 & 0.04 & $<0.01$ & 0.01 & $<0.01$ & $<0.01$ & $<0.01$ & $<0.01$ & $<0.01$ & $<0.01$ & $<0.01$ & $<0.01$ & $<0.01$ & $<0.01$ & $<0.01$ & $<0.01$ & $<0.01$ & 0.02 & $<0.01$ & $<0.01$ & -- \\
\hline Dissolved orthophosphorus $(\mathrm{mg} / \mathrm{L})$ & 0.01 & 0.01 & 0.01 & 0.15 & 0.01 & 0.02 & 0.02 & 0.04 & 0.04 & 0.02 & 0.01 & $<0.01$ & 0.02 & 0.02 & $<0.01$ & $<0.01$ & $<0.01$ & $<0.01$ & $<0.01$ & 0.01 & $<0.01$ & $<0.01$ & $<0.01$ & $<0.01$ & $<0.01$ & $<0.01$ & $<0.01$ & $\begin{array}{c}20.1 \\
\text { (total) }\end{array}$ \\
\hline Total hardness ( $\mathrm{mg} / \mathrm{L}$ as $\mathrm{CaCO}_{3}$ ) & -- & 67 & 93 & 160 & 52 & 91 & 98 & 72 & 73 & -- & 180 & 200 & 160 & 110 & 250 & 86 & 120 & 120 & -- & 78 & 170 & 180 & 150 & 130 & 170 & 90 & 200 & -- \\
\hline Dissolved calcium $(\mathrm{mg} / \mathrm{L})$ & 0. & 17 & 23 & 42 & 13 & 23 & 24 & 18 & 18 & $<0.02$ & 48 & 51 & 41 & 25 & 57 & 20 & 31 & 31 & $<0.02$ & 18 & 51 & 52 & 34 & 30 & 47 & 20 & 62 & 10.264 \\
\hline Dissolved magnesium (mg/L) & 0.004 & 6.1 & 8.8 & 14 & 4.6 & 8.1 & 9.0 & 6.9 & 6.9 & $<0.004$ & 16 & 17 & 13 & 13 & 25 & 9.1 & 9.4 & 9.4 & $<0.004$ & 8.2 & 9.9 & 14 & 16 & 13 & 14 & 9.8 & 12 & 1.377 \\
\hline Dissolved sodium $(\mathrm{mg} / \mathrm{L})$ & 0.06 & 13 & 20 & 11 & 5.0 & 11 & 22 & 13 & 13 & $<0.10$ & 60 & 420 & 10 & 9.2 & 16 & 8.6 & 10 & 10 & $<0.10$ & 8.3 & 8.9 & 18 & 13 & 10 & 9.6 & 7.7 & 13 & 26.553 \\
\hline Dissolved sodium adsorption rati & -- & 0.7 & 0.9 & 0.4 & 0.3 & 0.5 & 1 & 0.6 & 0.7 & -- & 2 & 13 & 0.4 & 0.4 & 0.4 & 0.4 & 0.4 & 0.4 & -- & 0.4 & 0.3 & 0.6 & 0.5 & 0.4 & 0.3 & 0.4 & 0.4 & -- \\
\hline Dissolved sodium, percent & -. & 29 & 32 & 13 & 17 & 20 & 32 & 27 & 27 & - & 41 & 82 & 13 & 15 & 12 & 18 & 16 & 16 & -- & 19 & 11 & 18 & 16 & 15 & 11 & 16 & 13 & -- \\
\hline $\operatorname{ssium~(mg/L)}$ & 0.1 & 2.7 & 3.5 & 3.6 & 1.7 & 4.6 & 4.0 & 3.3 & 3.4 & $<0.1$ & 4.2 & 6.6 & 2.8 & 2.6 & 2.9 & 2.0 & 1.8 & 2.0 & $<0.1$ & 2.2 & 2.0 & 3.1 & 1.7 & 2.0 & 2.2 & 2.5 & 2.4 & 0.087 \\
\hline Dissolved chloride ( $\mathrm{mg} / \mathrm{L}$ & 0.1 & 24 & 40 & 44 & 7.4 & 14 & 55 & 22 & 22 & $<0.1$ & 170 & 720 & 43 & 7.1 & 22 & 7.2. & 1.2 & 1. & $<0.1$ & 0.79 & 6.3 & 5.4 & 64 & 12 & 2.3 & 2.6 & 17 & -- \\
\hline Dissolved sulfate $(\mathrm{mg} / \mathrm{L})$ & 0.1 & 7.8 & 9.4 & 8.7 & 4.6 & 16 & 10 & 11 & 11 & $<0.1$ & 6.1 & 15 & 9.4 & 8.5 & 12 & 3.9 & 6.3 & 6.3 & $<0.1$ & 3.7 & 15 & 14 & 7.4 & 6.9 & 9.1 & 9.7 & 23 & -- \\
\hline Dissolved fluoride $(\mathrm{mg} / \mathrm{L}$ & 0.1 & 0.1 & 0.1 & 0.3 & 0.2 & 0.1 & 0.1 & 0.1 & 0.1 & $<0.1$ & 0.1 & $<0.1$ & 0.3 & 0.4 & 0.7 & 0.3 & 0.7 & 0.7 & $<0.1$ & 0.4 & 2 & 0.8 & 0.6 & 0.6 & 1 & 0.5 & 0.6 & -- \\
\hline Dissolved silica $(\mathrm{mg} / \mathrm{L})$ & 0.0 & 16 & 18 & 18 & 21 & 18 & 18 & 20 & 20 & 0.24 & 22 & 20 & 18 & 23 & 17 & 28 & 32 & 32 & 0.16 & 31 & 13 & 18 & 26 & 30 & 22 & 32 & 19 & -- \\
\hline Dissolved iron $(\mu \mathrm{g} / \mathrm{L})$ & 10 & 29 & $<10$ & $<10$ & 46 & 53 & $<10$ & $<10$ & $<10$ & $<10$ & $<10$ & $<30$ & 800 & 140 & $<10$ & 760 & 510 & 520 & $<10$ & 540 & $<10$ & 170 & 1,400 & 67 & 230 & 4,200 & $<10$ & 0.98 \\
\hline Dissolved boron $(\mu \mathrm{g} / \mathrm{L})$ & 16 & 34.3 & 68.7 & 31.9 & $<16.0$ & 70.2 & 74.8 & 65.6 & 67.9 & $<16.0$ & 258 & 32.6 & $<16.0$ & 58.7 & $<16.0$ & $<16.0$ & $<16.0$ & $<16.0$ & $<16.0$ & $<16.0$ & $<16.0$ & 20.5 & $<16.0$ & $<16.0$ & $<16.0$ & $<16.0$ & 284 & -- \\
\hline Dissolved manganese & 4.0 & 19 & $<4.0$ & $<4.0$ & 17 & 44 & $<4.0$ & $<4.0$ & $<4.0$ & $<4.0$ & $<4.0$ & $<12$ & 160 & 56 & 12 & 350 & 56 & 57 & $<4.0$ & 160 & 9.0 & 130 & 870 & 40 & 27 & 170 & $<4.0$ & 0.018 \\
\hline Dissolved solids, residue at $180^{\circ} \mathrm{C}(\mathrm{mg} / \mathrm{L})$ & 10 & 141 & 186 & 238 & 99.0 & 154 & 216 & 153 & 145 & $<10.0$ & 451 & 1350 & 234 & 168 & 286 & 138 & 172 & 176 & $<10.0$ & 132 & 222 & 263 & 244 & 195 & 243 & 161 & 309 & -- \\
\hline Total organic carbon $(\mathrm{mg} / \mathrm{L})$ & 0.2 & 3.6 & 2.6 & 2.4 & 2.3 & 1.6 & 2.0 & 1.4 & 1.5 & 0.2 & 1.2 & 1.9 & 1.9 & 0.9 & 0.6 & 0.4 & 0.2 & 0.2 & 0.3 & 0.2 & 0.8 & 0.6 & 0.4 & 0.2 & 0.5 & 0.4 & 1.3 & 58 \\
\hline UV abs & 0.001 & 0.259 & 0.081 & 0.061 & 0.068 & 0.036 & 0.067 & 0.036 & 0.037 & 0.004 & 0.028 & 0.04 & 0.077 & 0.021 & 0.01 & 0.010 & 0.010 & 0.008 & 0.00 & 0.006 & 0.013 & 0.01 & 0.01 & 0.009 & 0.013 & 0.015 & 0.026 & 1.34 \\
\hline Specific UV absorbance (uv254/TOC) & $\ldots$ & 0.072 & 0.031 & 0.025 & 0.030 & 0.023 & 0.033 & 0.026 & 0.024 & 0.016 & 0.024 & 0.026 & 0.040 & 0.023 & 0.019 & 0.026 & 0.042 & 0.041 & 0.018 & 0.029 & 0.016 & 0.018 & 0.028 & 0.036 & 0.027 & 0.041 & 0.020 & 0.023 \\
\hline Fluorescence, raw & - & 15.3 & 13.8 & 14.7 & 10.4 & 5.72 & -- & 5.09 & 5.11 & 0.347 & 5.24 & 9.47 & 9.33 & 3.04 & 1.87 & 0.938 & 0.839 & 0.474 & 0.146 & 0.190 & 2.02 & 1.36 & 0.506 & 0.325 & 1.01 & 0.814 & 3.74 & 58 \\
\hline Fle & -- & 16. & 13.5 & 14.3 & 10.8 & 5.65 & 9.73 & 4. & 4.88 & 0.415 & 5. & 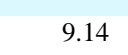 & 9.5 & 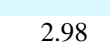 & 1.7 & 0.86 & 0.804 & 0.395 & 0.130 & 0.145 & 1.8 & 1. & 0.475 & 0.276 & 0.98 & 0.656 & 3.29 & 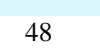 \\
\hline Fluorescence, percent change & -- & -4.6 & 2.2 & 2.8 & -20 & 3.0 & -- & 3.3 & 4.4 & -3.6 & 4.7 & 3.5 & -2.5 & 2.0 & 7.4 & 8.1 & 4.1 & 16.5 & 11 & 24 & 3.3 & 5.2 & 6.2 & 15 & 2.5 & 19 & 12 & 16 \\
\hline
\end{tabular}

${ }^{1}$ U.S. Geological Survey National Water Quality Laboratory world wide web page (http:///wwwnwq.cr.usgs.gov/).
${ }^{2}$ ISDS ion and nutrient analyses were performed by the City of Boulder wastewater laboratory; all values are total rather than dissolved, except as noted. 


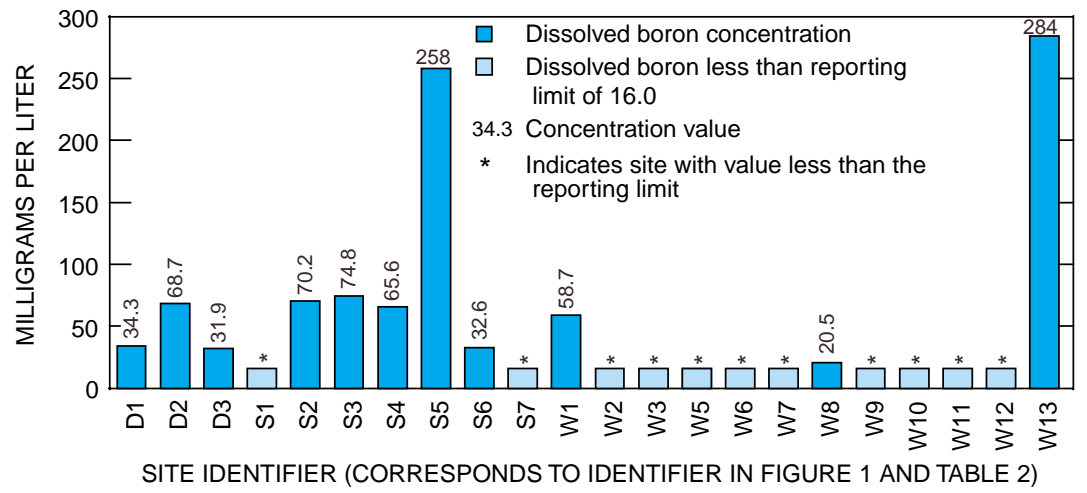

Figure 3. Dissolved boron concentrations in ground water and surface water.

well W1, which is not directly downgradient from site $\mathrm{S} 2$, was $58.7 \mu \mathrm{g} / \mathrm{L}$. Concentrations of boron at sites S5 and $\mathrm{W} 13$ were $258 \mu \mathrm{g} / \mathrm{L}$ and $284 \mu \mathrm{g} / \mathrm{L}$, respectively, indicating possible ISDS influence.

\section{Nutrients}

Nutrient analysis is the measurement of different forms of nitrogen and phosphorus in water. Nutrients are a concern in surface water because of eutrophication. In drinking water, including ground water, excess nutrients are a human health concern. The maximum contaminant level (MCL) in finished drinking water for nitrate is 10 milligrams per liter (mg/L) (U.S. Environmental Protection Agency, 1994). The median nitrate concentration from 30 ground-water sites in Boulder County in 1996 was $0.37 \mathrm{mg} / \mathrm{L}$ (Bruce and O'Riley, 1997). Sources of nitrogen include organic nitrogen (which is mineralized to nitrate) and fertilizers. Ammonia nitrogen that is applied at the surface in fertilizers or is output from an ISDS is usually converted by nitrification to ionic nitrate in the soil (Freeze and Cherry, 1979). Nitrate can be useful as a tracking tool for ISDS contamination because large concentrations can be contributed by human waste, and nitrate is mobile in water. Analysis was done at all sites in this study for nitrite plus nitrate (table 2). The nitrite concentrations were so small that the results of this analysis are referred to as nitrate in this report. Five wells had nitrate concentrations greater than the reporting limit of $0.05 \mathrm{mg} / \mathrm{L}$ and greater than the 1996 median of $0.37 \mathrm{mg} / \mathrm{L}$ (fig. 4); wells W1 and W13 had large concentrations of nitrate ( 2.4 and $9.3 \mathrm{mg} / \mathrm{L})$, possibly indicating an anthropogenic source. These wells also had greater boron concentrations than the other wells. The nitrate concentrations were greater at surface-water sites S3, S4, and D2 $(1.9,1.8$, and $2.5 \mathrm{mg} / \mathrm{L}$, respectively) than in the upgradient $\mathrm{S} 2(0.14 \mathrm{mg} / \mathrm{L})$; greater in D1 $(2.3 \mathrm{mg} / \mathrm{L})$ than in upgradient $\mathrm{S} 1$ (<0 $0.05 \mathrm{mg} / \mathrm{L})$; and greater in D3 $(1.9 \mathrm{mg} / \mathrm{L})$ than in upgradient $\mathrm{S} 7$ $(1.3 \mathrm{mg} / \mathrm{L})$. The largest nitrate concentration in a surface-water sample was from site S5 $(4.8 \mathrm{mg} / \mathrm{L})$. Concentrations of nitrate were greater than ammonia nitrogen in all of the samples except the ISDS. The nitrogen in the ISDS is in the form of ammonia rather than nitrate because the sample was collected before discharge to

Phosphorus, which is an ingredient in detergents and cleaners, also can be an indicator of septic contamination. Orthophosphorus is the major inorganic form of phosphorus. The ISDS had the soil, where nitrification occurs. in ground water and surface water. water and surface water. considerable concentrations of dissolved phosphorus and dissolved orthophosphorus (19.2 and $20.1 \mathrm{mg} / \mathrm{L}$ ). The phosphorus concentrations were not substantial for most other sites (fig. 5), possibly because phosphorus is readily removed in the subsurface by sorption and precipitation (Canter and Knox, 1986; Hem, 1992). Phosphorus was not detected at significant concentrations in the wells and springs with the greatest concentrations of boron and nitrate. The largest dissolved phosphorus concentrations were found at sites D3 $(0.15 \mathrm{mg} / \mathrm{L})$ and S4 $(0.03 \mathrm{mg} / \mathrm{L})$. Site D3 $(0.15 \mathrm{mg} / \mathrm{L})$ was the only site, aside from the ISDS $(20.1 \mathrm{mg} / \mathrm{L})$, with an orthophosphorus concentration greater than $0.05 \mathrm{mg} / \mathrm{L}$.

\section{Bacteria}

Fecal coliform bacteria are present in human and animal wastes. Fecal coliform were not detected in any well north of Barker Reservoir but were detected at surface-water site D3 (fig. 6). Fecal coliform bacteria were detected at many of the surfacewater sites south of Barker Reservoir; the largest concentration was at site D1. Wild or domestic animals might be contributing to the fecal coliform concentrations in surface water, such as that in

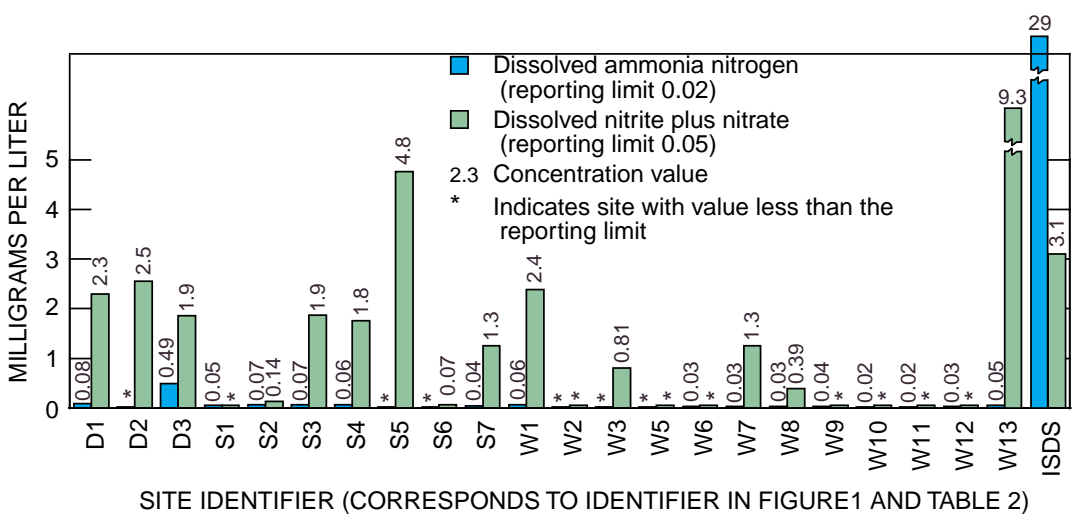

Figure 4. Dissolved nitrite plus nitrate and dissolved ammonia nitrogen concentrations

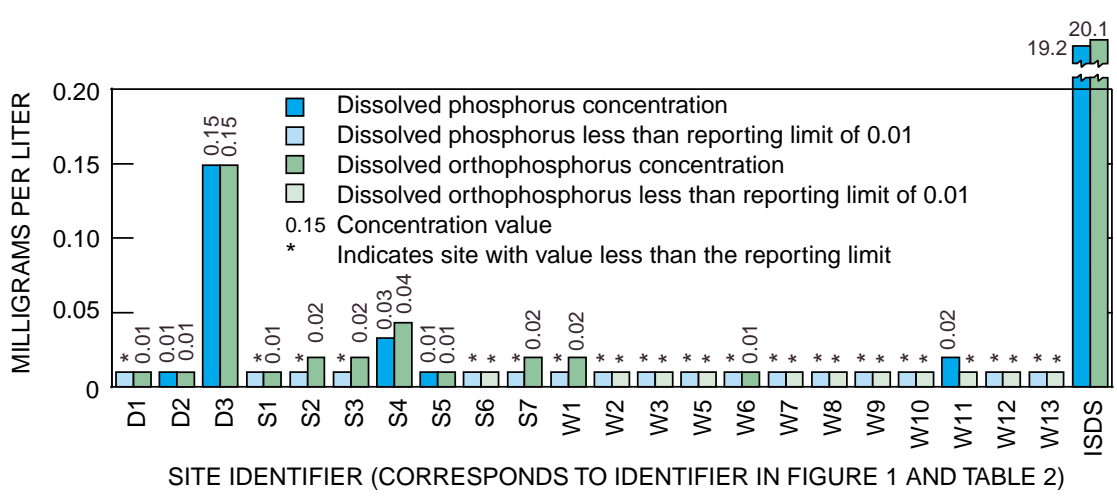

Figure 5. Dissolved phosphorus and dissolved orthophosphorus concentrations in ground 
the upgradient surface-water site $\mathrm{S} 2$. However, site D1 is downgradient from several ISDS's; thus, it is possible that the contamination is from residential sources. The fecal coliform, boron, and nitrate concentrations for site D1 are all greater than those for the upgradient site $\mathrm{S} 1$. The fecal coliform from W1, the only well sampled south of Barker Reservoir, is possibly from anthropogenic sources; this also is indicated by the concentration of boron and nitrate.
A fecal coliform sample was not collected from the ISDS because it was presumed that the number of colonies would be too high for the laboratory to analyze. Fecal coliform in ISDS's can range from 420,000 to 5,000,000 colonies per 100 milliliters (Canter and Knox, 1986). Subsurface transport is an effective removal process for bacteria but not for nitrate and boron, as indicated by the absence of bacteria in the well with the large concentrations of nitrate and boron (W13).

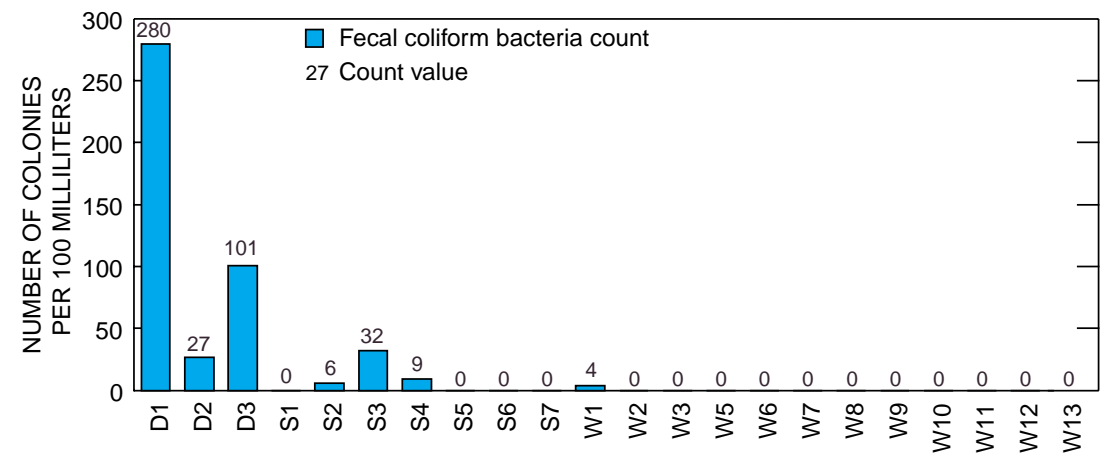

SITE IDENTIFIER (CORRESPONDS TO IDENTIFIER IN FIGURE 1 AND TABLE 2)

Figure 6. Fecal coliform bacteria number in ground water and surface water.

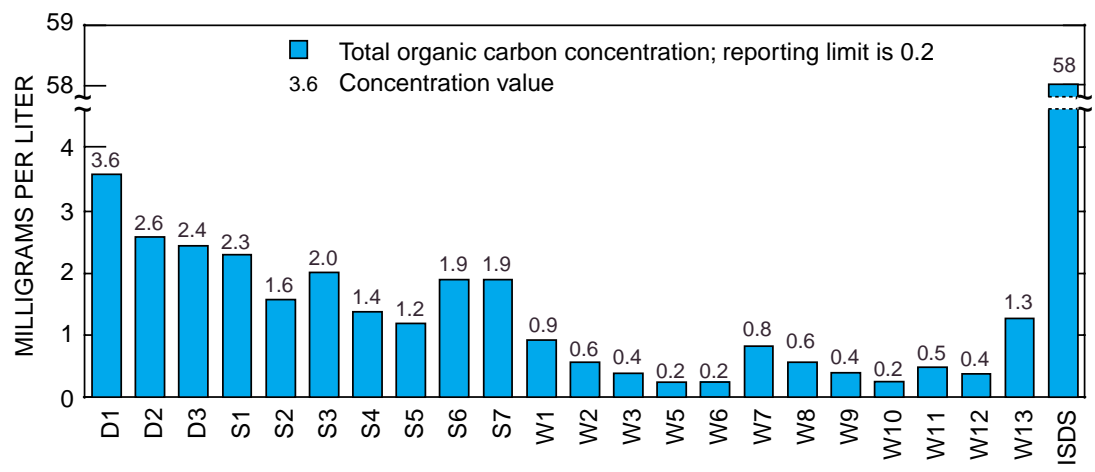

SITE IDENTIFIER (CORRESPONDS TO IDENTIFIER IN FIGURE 1 AND TABLE 2)

Figure 7. Total organic carbon (TOC) concentrations in ground water and surface water.

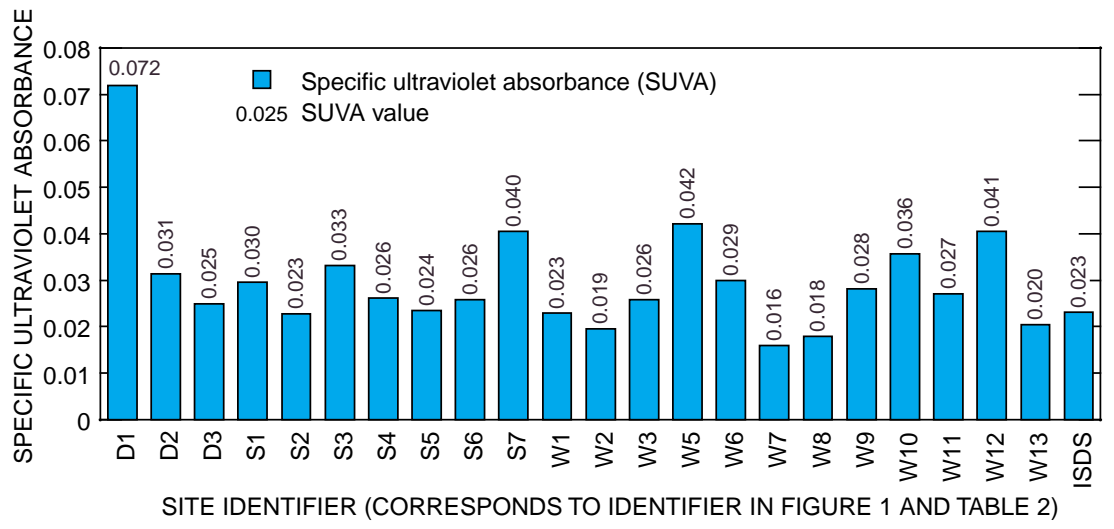

Figure 8. Specific ultraviolet absorbance (uv254/TOC) in ground water and surface water.

\section{Total Organic Carbon}

Total organic carbon (TOC) is a measurement of all forms of organic carbon present in a water sample. Groundwater concentrations are typically lower than surface-water concentrations because of biodegradation and soil adsorption of organic material during aquifer recharge and because of leaching of plant-derived soil organic matter into surface water. ISDS effluent is highly enriched in TOC because of the biological wastes containing natural biogenic carbon and synthetic organic compounds used in consumer products. The ISDS sampled in this study had $58 \mathrm{mg} / \mathrm{L}$ of TOC (table 2 and fig. 7). Substantial removal of TOC can occur during anaerobic degradation in the septic tank and percolation through the leach field and unsaturated zone. Even with removal, properly functioning ISDS's and wastewater infiltration systems can contribute significant TOC concentrations into ground water (Barber and others, 1988; Wilhelm and others, 1994; Barber and others, 1997).

Most of the surface-water TOC concentrations were greater than the groundwater concentrations, and spring-water concentrations were intermediate (fig. 7). TOC concentrations at the downgradient sites D1, D2, and D3 (3.6, 2.6, and $2.4 \mathrm{mg} / \mathrm{L}$, respectively) were greater than the upgradient sites $\mathrm{S} 1, \mathrm{~S} 2$, and $\mathrm{S} 7$ (2.3, 1.6 , and $1.9 \mathrm{mg} / \mathrm{L}$, respectively) because the flowing water interacts with plant detritus and soil organic matter. The largest ground-water concentrations were at well W1 $(0.9 \mathrm{mg} / \mathrm{L})$ south of Barker Reservoir and wells W7 (0.8 mg/L) and W13 (1.3 mg/L) north of Barker Reservoir. Nitrate concentrations at all three of these well sites were relatively high, and boron concentrations at two of these sites (W1 and W13) also were high.

\section{UV Absorbance}

Light absorption measurements (ultraviolet light absorbance at 254 nanometers, UV254) can indicate differences in TOC characteristics. The molecular structure of natural organic material has different light absorption properties than those of synthetic detergents. The sulfonated aromatic rings in synthetic detergents absorb less UV light than the phenol-substituted aromatic rings of natural humic substances (J. Leenheer, U.S. Geological Survey, written commun., 1999).

UV absorption measurements are more easily compared when they are normalized by dividing the UV254 by the TOC concentration. This measurement is called specific UV absorbance, or SUVA (fig. 8). An inverse relation between SUVA and septic contamination should exist. The relatively large SUVA reading at site D1 shows the influence of plant and soil organic matter on TOC, whereas 


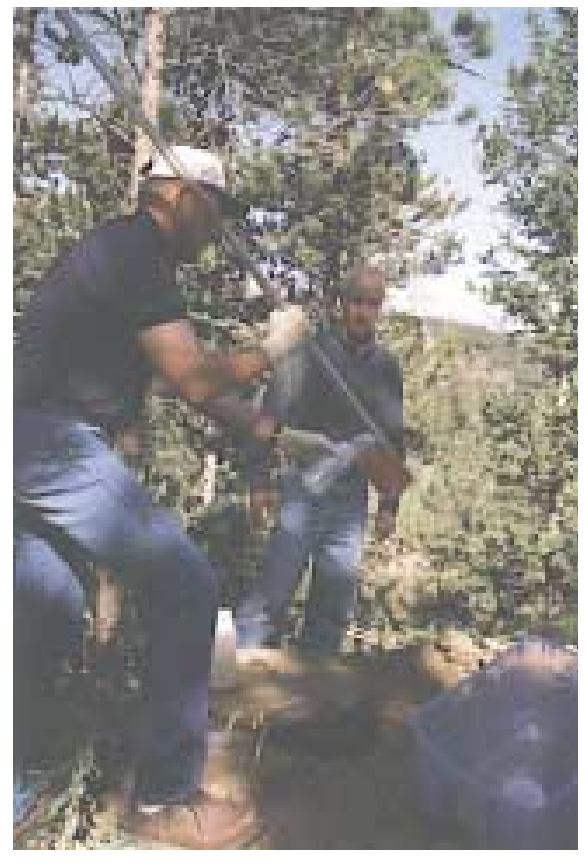

Sample collection from an individual sewage disposal system.

the lower SUVA reading at the ISDS indicates a different TOC source. The spring and ground-water SUVA values are variable and show no obvious trend.

\section{Conclusions}

Analyses of ground water north of Barker Reservoir do not indicate widespread contamination, although isolated areas have concentrations of septic indicators such as boron, nitrate, and TOC that are larger than at other areas. The sites that show the greatest concentrations of indicator constituents (for example, S5, W3, W7, and W13) are at residences that are older than the other residences north of Barker Reservoir in this study, and contaminants may have had more time to reach the ground water. Surface-water site D3 had greater concentrations of nitrate, phosphorus, fecal coliform, and TOC than upgradient site S7.

South of Barker Reservoir, downgradient surface-water sites (D1, D2, S3, and S4) had greater concentrations of some constituents than upgradient surface-water sites (S1 and S2). The contamination could be from runoff in the area or from wildlife and domestic animals but also could indicate ISDS contamination. Ground-water data are limited south of the reservoir, with only one relatively shallow well to sample (well W1). Concentrations of nitrate, boron, fecal coliform, and TOC at this site were suggestive of possible ISDS effects. Data from more wells are needed to determine the extent and magnitude of ground-water contamination.

This study had a limited analyte list of a few indicator compounds. ISDS effluents are very complex, and the presence of indicator compounds might indicate that other potentially detrimental compounds also may be present.

\section{References}

Barber, L.B., II, Thurman, E.M., Schroeder, M.P., and LeBlanc, D.R., 1988, Longterm fate of organic micropollutants in sewage-contaminated groundwater: Environmental Science and Technology, v. 22, no. 2, p. 205-211.

Barber, L.B., II, Brown, G.K., Kennedy, K.R., Leenheer, J.A., Noyes, T.I., Rostad, C.E., and Thorn, K.A., 1997, Organic constituents that persist during aquifer storage and recovery of reclaimed water in Los Angeles County, California: Proceedings, American Water Resources Association symposium, Conjunctive Use of Water Resources-Aquifer Storage and Recovery, October 19-23, 1997, Long Beach, Calif., Technical Publication Series TPS, v. 97-2, p. 261-272.

Barnett, P.R., Skougstad, M.W., and Miller, K.J., 1969, Chemical characterization of a public water supply: Journal of American Water Works Association, February, v. 61, no. 2, p. 60-67.

Bruce, B.W., and O'Riley, Christopher, 1997, Comparative study of groundwater quality, 1976 and 1996, and initial gain-and-loss assessment of Boulder Creek, Boulder County, Colorado: U.S. Geological Survey Water-Resources Investigations Report 97-4091, 49 p.

Canter, Larry, and Knox, R.C., 1986, Septic tank system effects on ground-water quality: Chelsea, Mich., Lewis Publishers, Inc., 180 p.

Freeze, R.A., and Cherry, J.A., 1979, Groundwater: Englewood Cliffs, New Jersey, Prentice-Hall, Inc., p. 413-416.
Gable, D.J., 1972, Geologic map of the Tungsten quadrangle-Boulder, Gilpin, and Jefferson Counties, Colorado: U.S. Geological Survey Geologic Quadrangle Map GQ-978, scale 1:24,000.

Hem, J.D., 1992, Study and interpretation of the chemical characteristics of natural waters: U.S. Geological Survey WaterSupply Paper 2254, 263 p.

Lovering, T.S., and Goddard, E.N., 1950, Geology and ore deposits of the Front Range, Colorado: U.S. Geological Survey Professional Paper 223, 319 p., 30 plates.

U.S. Environmental Protection Agency, February 1994, National Primary Drinking Water Standards: EPA 810-F-94-001.

Waggott, A., 1969, An investigation of the potential problems of increasing boron concentrations in rivers and water courses: Water Research, v. 3, p. 749-765.

Wilhelm, S.R., Schiff, S.L., and Robertson, W.D., 1994, Chemical fate and transport in a domestic septic systemUnsaturated and saturated zone geochemistry: Environmental Toxicology and Chemistry, v. 13, p. 193-203.

\section{Acknowledgments:}

Thanks to the property owners who allowed the USGS to include their wells in this study.

Sampling assistance: Jim Shelley, Scot Gillespie, and James Stout from the City of Boulder; Ann Weise and Mark Williams from the Boulder County Health Department.

Water-quality analysis: Jodi Hogan of the Boulder County Health Department; Steffanie Keefe and Kate Campbell of the USGS; City of Boulder wastewater laboratory.

Photographs: Jim Shelley

—Jennifer L. Flynn and L.B. Barber

\section{Information on technical and hydrological data can be obtained from: \\ District Chief \\ U.S. Geological Survey \\ Water Resources Division \\ Box 25046, Mail Stop 415 \\ Denver, CO 80225-0046 \\ (303) 236-4882, ext. 258}

